\title{
Spatial-temporal variation in litterfall in seasonally dry tropical forests in Northeastern Brazil
}

\author{
V. F. P. Araújo (D, M. R. V. Barbosa ${ }^{b}$ (D), J. P. Araújo ${ }^{b}$ (D) and A. Vasconcellos ${ }^{b *}$ \\ ${ }^{a}$ Colegiado de Ciências da Natureza, Universidade Federal do Vale do São Francisco - UNIVASF, Campus Senhor do \\ Bonfim, CEP 48970-000, Senhor do Bonfim, BA, Brasil \\ bDepartamento de Sistemática e Ecologia, Centro de Ciências Exatas e da Natureza, Universidade Federal da Paraíba - \\ UFPB, CEP 58051-900, João Pessoa, PB, Brasil \\ *e-mail: avasconcellos@dse.ufpb.br
}

Received: February 26, 2018 - Accepted: October 25, 2018 - Distributed: May 31, 2020

(With 2 figures)

\begin{abstract}
The production of litterfall is essential for nutrient cycling in terrestrial ecosystems. From November 2009 to October 2011, analyzed the monthly litterfall production in two areas of Caatinga, a type of Seasonally Dry Tropical Forest located in the Cariri Paraibano, in the semiarid region of the Paraíba, Northeastern Brazil. One of the areas, Private Natural Heritage Reserve (RPPN) Fazenda Almas, is legally protected, and the other, Fazenda Moreiras, does not. The aims were to evaluate the effects of precipitation, evapotranspiration and vegetation structure on the temporal and spatial dynamics of litterfall production. Eight sampling points were randomly chosen at each site, and two $1 \mathrm{~m}^{2}$ collectors were installed $50 \mathrm{~m}$ apart from each other. The collected material was sorted, dried and weighed. Additionally, the characteristics (density, species richness, height and mean basal area) of the tree-shrub stratum in plots with a $10 \mathrm{~m}$ radius surrounding each collector. Total litterfall production was 4,500 $\mathrm{kg} \mathrm{ha}^{-1} \mathrm{yr}^{-1}$ for Fazenda Almas and 3,300 $\mathrm{kg} \mathrm{ha}^{-1} \mathrm{yr}^{-1}$ for Fazenda Moreiras; these values were within the expected range for Seasonally Dry Tropical Forests. The inter- and intra-annual variation in litterfall production was positively correlated with precipitation and evapotranspiration rates, and four months after the highest precipitation rates, there was a marked decrease in litterfall occurred during the dry season. Furthermore, the contributions of the material fractions were distinct with the leaf fraction representing for more than $60 \%$ of the litterfall, and the vegetation structure explained $75 \%$ of the variation in litterfall production. Therefore, climatic factors and vegetation structure affect the temporal and spatial dynamics of litterfall production and consequently influence nutrient dynamics in the semiarid region of Brazil.
\end{abstract}

Keywords: biomass, Caatinga, evapotranspiration, rainfall, semiarid, vegetation.

\section{Variação espaço-temporal da serapilheira em uma floresta tropical sazonalmente seca no Nordeste do Brasil}

\section{Resumo}

A produção de serapilheira é essencial para a ciclagem de nutrientes em ecossistemas terrestres. De Novembro de 2009 a Outubro de 2011, foi analisada a produção de serapilheira em duas áreas de Caatinga, um tipo de Floresta Tropical sazonalmente Seca localizada no Cariri Paraibano, na região do semiárido da Paraíba, Nordeste do Brasil. Uma das áreas, Reserva Particular do Patrimônio Natural - RPPN - Fazenda Almas, é legalmente protegida, ao contrário da outra, Fazenda Moreiras. Os objetivos foram avaliar o efeito da precipitação, evapotranspiração e estrutura da vegetação sobre a dinâmica temporal e espacial da produção de serapilheira. Oito pontos de amostragem foram escolhidos aleatoriamente em cada localidade, e dois coletores de $1 \mathrm{~m}^{2}$ foram instalados a $50 \mathrm{~m}$ um do outro. O material coletado foi triado, secado e pesado. Adicionalmente, foram registradas as características (densidade, riqueza de espécies, altura e área basal média) das espécies arbóreo-arbustivas na parcela com um raio (r) de $10 \mathrm{~m}$ ao redor de cada coletor. A produção total de serapilheira foi 4,500 $\mathrm{Kg} \mathrm{ha}^{-1} \mathrm{yr}^{-1}$ para a Fazenda Almas e 3,300 $\mathrm{kg} \mathrm{ha}^{-1} \mathrm{yr}^{-1}$ para a Fazenda Moreiras; estes valores estão dentro da faixa esperada para as Florestas Tropicais sazonalmente secas. A variação inter e intranual na produção de serapilheira foi positivamente correlacionada com as taxas de precipitação e evapotranspiração, e quatro meses depois das maiores taxas de precipitação, houve uma diminuição acentuada na serapilheira coletada durante a estação seca. Além disso, as contribuições das frações de material foram distintas com a fração de folha representando mais que $60 \%$ da serapilheira, e a estrutura da vegetação explicou $75 \%$ da variação na produção de serapilheira. Portanto, os fatores climáticos e a estrutura da vegetação afetam a dinâmica temporal e espacial da produção de serapilheira e, consequentemente, influenciam a dinâmica de nutrientes na região semiárida do Brasil.

Palavras-chave: biomassa, Caatinga, evapotranspiração, pluviosidade, semiárido, vegetação. 


\section{Introduction}

Litterfall production is considered one of the main routes of nutrient transfer from the vegetation to the soil (Vitousek, 1984; Búrquez et al., 1999; Vital et al., 2004). Therefore, quantifying litterfall pools is essential to properly understand the structure and function of tropical forests (Bray and Gorham, 1964; Vital et al., 2004). In semiarid terrestrial ecosystems, litterfall production provides important information about the phenological cycles of plants and their influence on the return of nutrients to the soil (Proctor et al., 1983). Thus, understanding the dynamics of litterfall production can provide insight into nutrient cycling, forest growth, successional patterns, carbon fluxes, ecological disturbances and the interactions among environmental variables in forest ecosystems (Vasconcelos and Luizão, 2004; Zhou et al., 2007; González-Rodríguez et al., 2011).

In Seasonally Dry Tropical Forests (SDTF), primary productivity is largely controlled by the amount and duration of rainfall, so seasonal variations in rainfall constrain and control the productivity and nutrient dynamics of these ecosystems (Lugo and Murphy, 1986; Dirzo et al., 2011). In arid and semiarid environments, variations in vegetation structure, caused by edaphic factors and distribution of rainfall, can also lead to spatial changes in litterfall production (Archer et al., 1988; Facelli and Pickett, 1991; Alvarez et al., 2009; Bisigato et al., 2009).

Caatinga, a type of SDTF in South America (Prado and Gibbs, 1993), covers an area of approximately $735,000 \mathrm{~km}^{2}$, in Northeastern Brazil. This region is characterized by high temperatures and water deficits that exacerbate the effects of poorly distributed low rainfall (Reis, 1976; Andrade-Lima, 1981). The landscape is dominated by a mosaic of physiognomic forms, particularly with xerophytic plant species (Medeiros et al., 2009). The aerial biomass ranges between 30,000 and 50,000 kg ha-1 (Menezes et al., 2012). In the Caatinga, the vegetation cover and litterfall are important for soil protection because the soil is usually shallow with low infiltration capacity, high surface runoff and reduced natural drainage (Sampaio et al., 1981; Lopes et al., 2009).

There are only a few studies on the production and accumulation of litter in the caatinga (Andrade et al., 2008; Costa et al., 2010; Santos et al., 2011; Silva et al., 2015b), as well as about its degradation rate (Sampaio, 1995; Dantas, 2003; Alves et al., 2006; Lopes et al., 2009; Santana and Souto, 2011; Menezes et al., 2012; Bauer et al., 2016). Our hypothesis is that variations in litter production in the Caatinga could occur due to variations in climatic factors and variations in the structures of natural ecosystems. Areas more impacted by anthropogenic action would have less plant diversity and less litter production. The present study sought to evaluate the effect of precipitation, evapotranspiration and vegetation structure on the spatial-temporal dynamics of litterfall production in one of the driest region of SDTF in Northeastern Brazil.

\section{Materials and Methods}

This study was conducted between November 2009 and October 2011 in two localities in the Cariri Paraibano: Fazenda Moreiras and a Private Natural Heritage Reserve (RPPN) Fazenda Almas, both in the semiarid region in northeastern Brazil. Fazenda Almas (07 $28^{\prime} 15^{\prime}$ 'S and $\left.36^{\circ} 52^{\prime} 51^{\prime \prime} \mathrm{W}\right)$ is one of the best-preserved areas in the region, with approximately 3,505 ha extending between 600 and $720 \mathrm{~m}$ above sea level, and it is located in the municipality of São José dos Cordeiros (Barbosa et al., 2007). Fazenda Moreiras (07²3'51'S and 36²4'49.1'W), with an area of ca. 499 ha and approximately $460 \mathrm{~m}$ above sea level, is a private property, which is representative of the land use reality in the region, presents a comparatively more altered vegetation, on the banks of the Taperoá River in the municipality of São João do Cariri (Carvalho and Carvalho, 1985) (Figure 1).

The climate in the region is BSh, according to the Köppen classification (Alburqueque et al., 2005); rainfall is concentrated in three or four months, and ranges between 250 and $900 \mathrm{~mm}$ per year. Average annual temperatures are relatively high, surface temperature values ranged between 21.8 and $34.7{ }^{\circ} \mathrm{C}$, net radiation ranged from 532.22 to $732.66 \mathrm{~W} / \mathrm{m}^{2}$ and potential evapotranspiration from 3.99 to $6.64 \mathrm{~mm} /$ day (Silva et al., 2015a). Relative humidity rarely exceeds $75 \%$ (Barbosa et al., 2007). Soils are shallow and rocky (Sampaio et al., 1981).

Eight sampling points were randomly chosen at each site, and two $1 \mathrm{~m}^{2}$ collectors were installed $50 \mathrm{~m}$ apart from
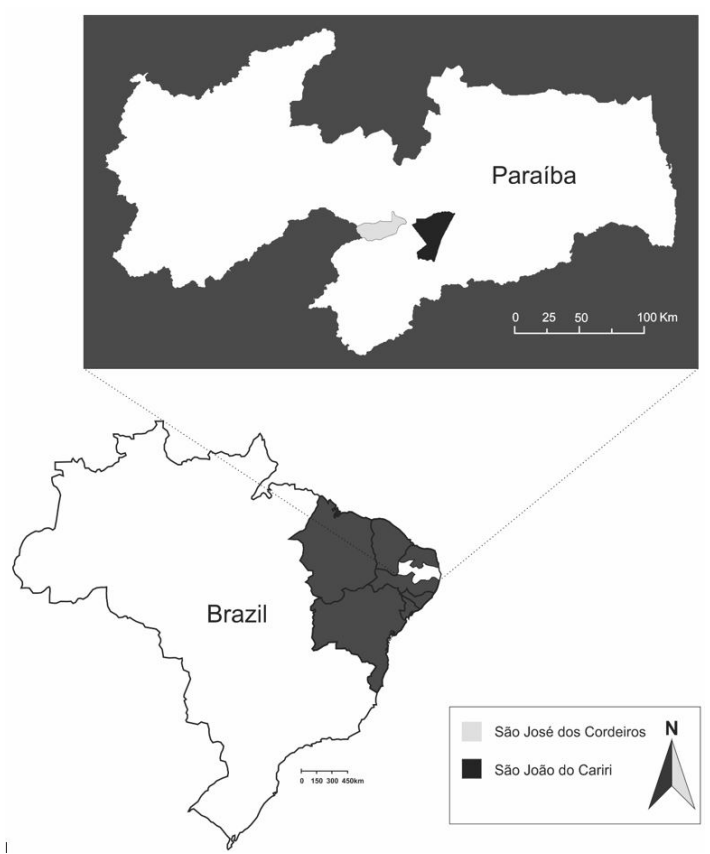

Figure 1. Map of Northeast Brazil showing the municipalities of São José dos Cordeiros (Fazenda Almas) and São João do Cariri (Fazenda Moreiras), in the Cariri Paraibano. 
each other at each point. Collectors were wooden frames covered with $1 \mathrm{~mm}$ nylon mesh suspended approximately $20 \mathrm{~cm}$ above the ground. The litterfall gathered in each collector was removed once a month (between November 2009 and October 2011) and manually sorted in the laboratory into four fractions: leaves (including leaflets and petioles), branches (including bark and other woody parts), reproductive structures (flowers, fruits and seeds) and miscellaneous material that could not be precisely identified. The different fractions were dried in a forced-air oven at $60^{\circ} \mathrm{C}$ for $72 \mathrm{~h}$ and then weighed to an accuracy of four decimal places using a precision balance.

To analyze temporal variation, was correlated litterfall production, accumulated rainfall and actual evapotranspiration in both localities. Climatic data were provided by the Programa de Monitoramento Climático em Tempo Real da Região Nordeste (Northeastern Region Real-time Climate Monitoring Program - PROCLIMA, 2011). To analyze spatial heterogeneity, the relationship between litterfall production and vegetation structure (density, species richness, medium height and mean basal area of tree and shrubby species) at each sampling point was investigated. Plots with radii (r) of approximately $10 \mathrm{~m}$ were installed around each collector, and within that all living plants with a stem diameter at ground level (DGL) $\geq 3 \mathrm{~cm}$ and total height $(\mathrm{TH}) \geq 1 \mathrm{~m}$ were sampled and measured (Barbosa et al., 2007). Density, species richness, height and mean basal area of the plots were calculated using FITOPAC software (Shepherd, 2008).

\section{Statistical Analysis}

Two sampling periods denominated year 1 (November 2009 to October 2010) and year 2 (November 2010 to October 2011) were considered. The annual litterfall production for each sampling point was calculated with the average obtained from the two collectors.

Repeated measures ANOVA were used to analyze the temporal variation in litterfall production between years and months, and Spearman's correlations between litterfall production and climatic data (precipitation and evapotranspiration) recorded 30, 60, 90 and 120 days prior to the sampling events were estimated. A General Linear Models (GLM) analysis was performed to evaluate the relationship between spatial variability of litter production and vegetation structure. To meet the assumption of normality, the data were $\log (\mathrm{x}+1)$ transformed. The analyses were performed using STATISTICA 5.0 (StatSoft, 1995).

\section{Results}

Litterfall production at RPPN Fazenda Almas totaled approximately $4,580 \mathrm{~kg} \mathrm{ha}^{-1} \mathrm{yr}^{-1}$ with a monthly average ( \pm standard error) of $380 \pm 40 \mathrm{~kg} \mathrm{ha}^{-1}$. The highest rates of production occurred in July $2011\left(860 \mathrm{~kg} \mathrm{ha}^{-1}\right)$ and August $2011\left(846 \mathrm{~kg} \mathrm{ha}^{-1}\right)$, and the lowest rates were in December 2009 and October $2010\left(151 \mathrm{~kg} \mathrm{ha}^{-1}\right.$ and $103 \mathrm{~kg} \mathrm{ha}^{-1}$, respectively) (Table 1). At Fazenda Moreiras, the annual production was approximately $3,320 \mathrm{~kg} \mathrm{ha}^{-1} \mathrm{yr}^{-1}$ with a monthly average of $280 \pm 30 \mathrm{~kg} \mathrm{ha}^{-1}$. The highest production rates occurred in April 2011 and August 2011 (458 and $577 \mathrm{~kg} \mathrm{ha}^{-1}$, respectively), and the lowest in November 2010 and December 2010 (90 and $100 \mathrm{~kg} \mathrm{ha}^{-1}$, respectively) (Table 1).

The accumulated annual rainfall was greater than $700 \mathrm{~mm}$ at both sites during the year 1 (November 2009 to October 2010), with precipitation greater than $60 \mathrm{~mm}$ month $^{-1}$ for four consecutive months (January-April 2010). In the year 2 (November 2010-October 2011), annual rainfall was greater than $1,000 \mathrm{~mm}$ with five consecutive months exceeding $100 \mathrm{~mm}^{\text {month }}{ }^{-1}$ (January-May 2011) (Figure 2A and 2B). There was significant variation in the total production of litterfall between months but not between years for both RPPN Fazenda Almas (Month: $\mathrm{F}_{11,180}=14.18, \mathrm{p}<0.001$; Year: $\left.\mathrm{F}_{1,180}=0.05, \mathrm{p}>0.05\right)$ and Fazenda Moreiras (Month: $\mathrm{F}_{11,180}=4.48, \mathrm{p}<0.001$; Year: $\left.\mathrm{F}_{1,180}=1.54, \mathrm{p}>0.05\right)$. However, the temporal heterogeneity in litterfall production responded to variations between years and months (Year x Month - Fazenda Almas: $\mathrm{F}_{11,180}=7.13, \mathrm{p}<0.001$; Fazenda Moreiras: $\mathrm{F}_{11,180}=1.91$, $\mathrm{p}<0.05$ ) (Table 2).

The rate of litterfall production correlated most strongly with rainfall in the fourth month prior to sampling $\left(r_{s 60 \text { days }}=0.32, \mathrm{n}=48, \mathrm{p}<0.05 ; \mathrm{r}_{\mathrm{s} 90 \text { days }}=0.36, \mathrm{n}=48, \mathrm{p}<0.05\right.$;
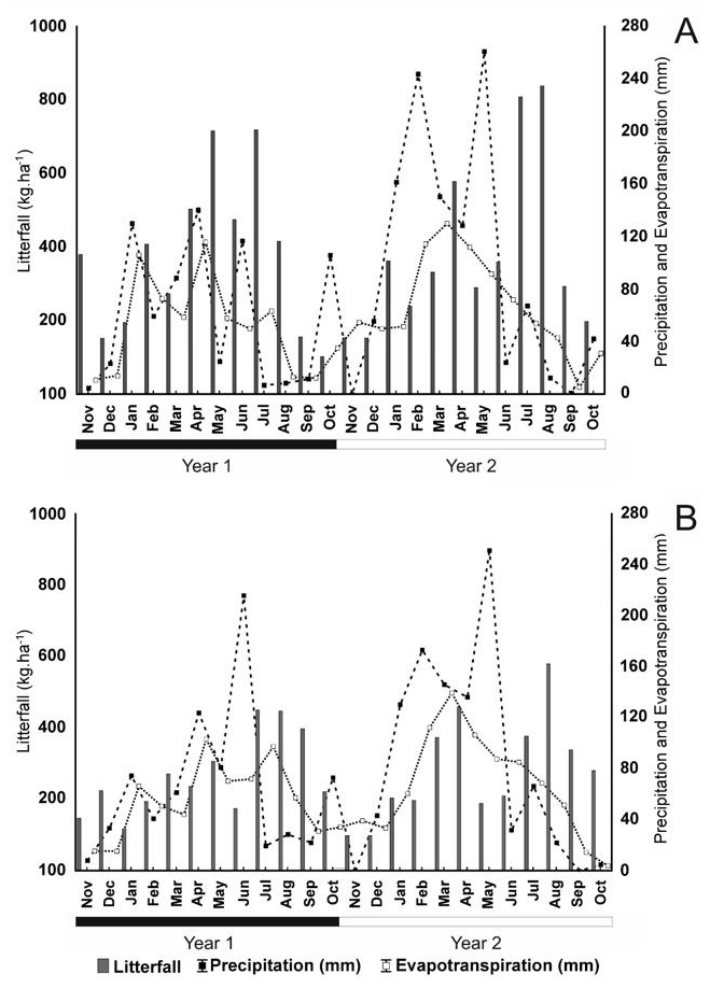

Figure 2. Temporal variations in litterfall production, evapotranspiration and rainfall between November 2009 and October 2011 at RPPN Fazenda Almas (A), São José dos Cordeiros and Fazenda Moreiras (B), São João do Cariri, Paraíba state, Brazil. The values are the means. 


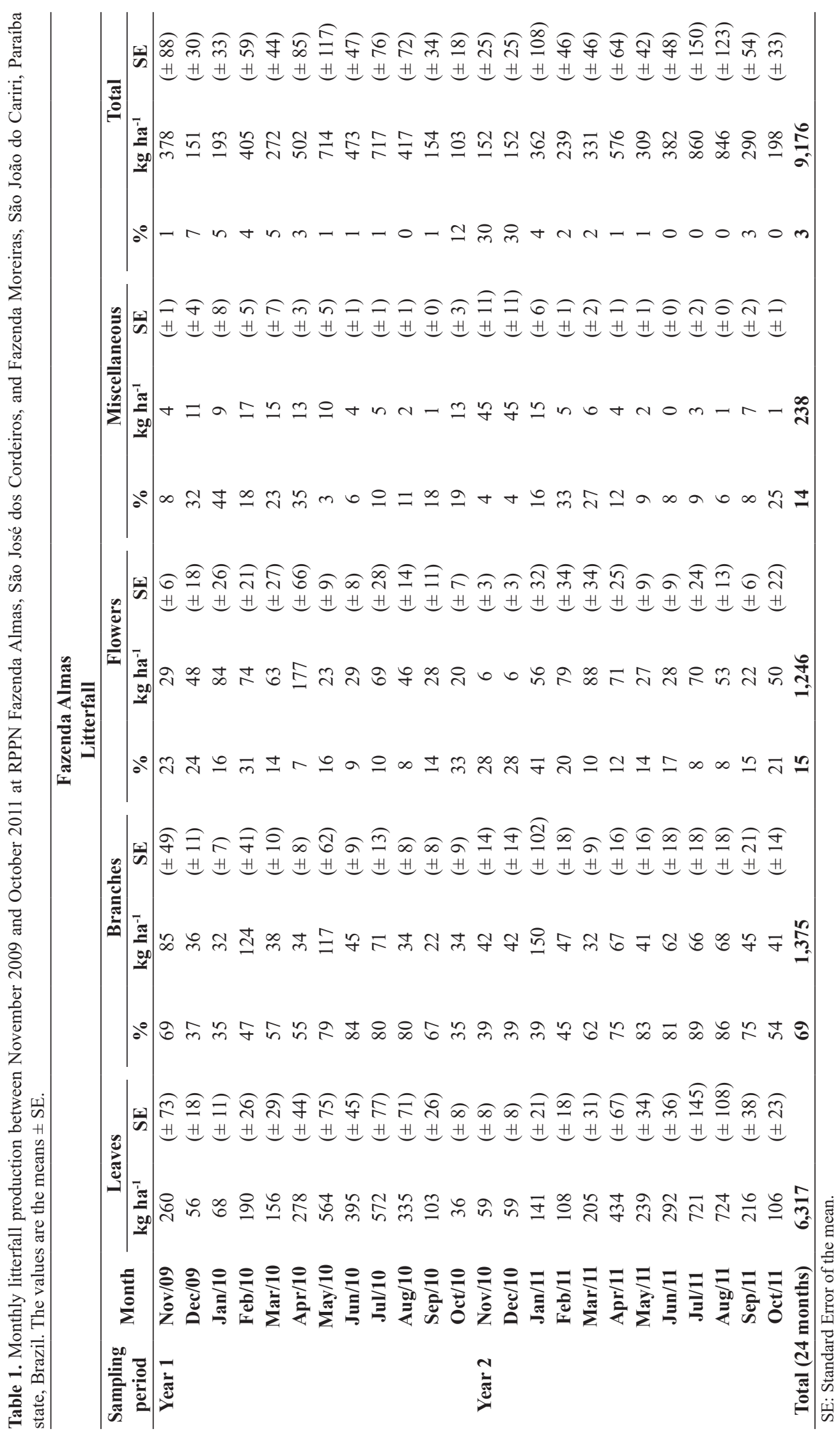




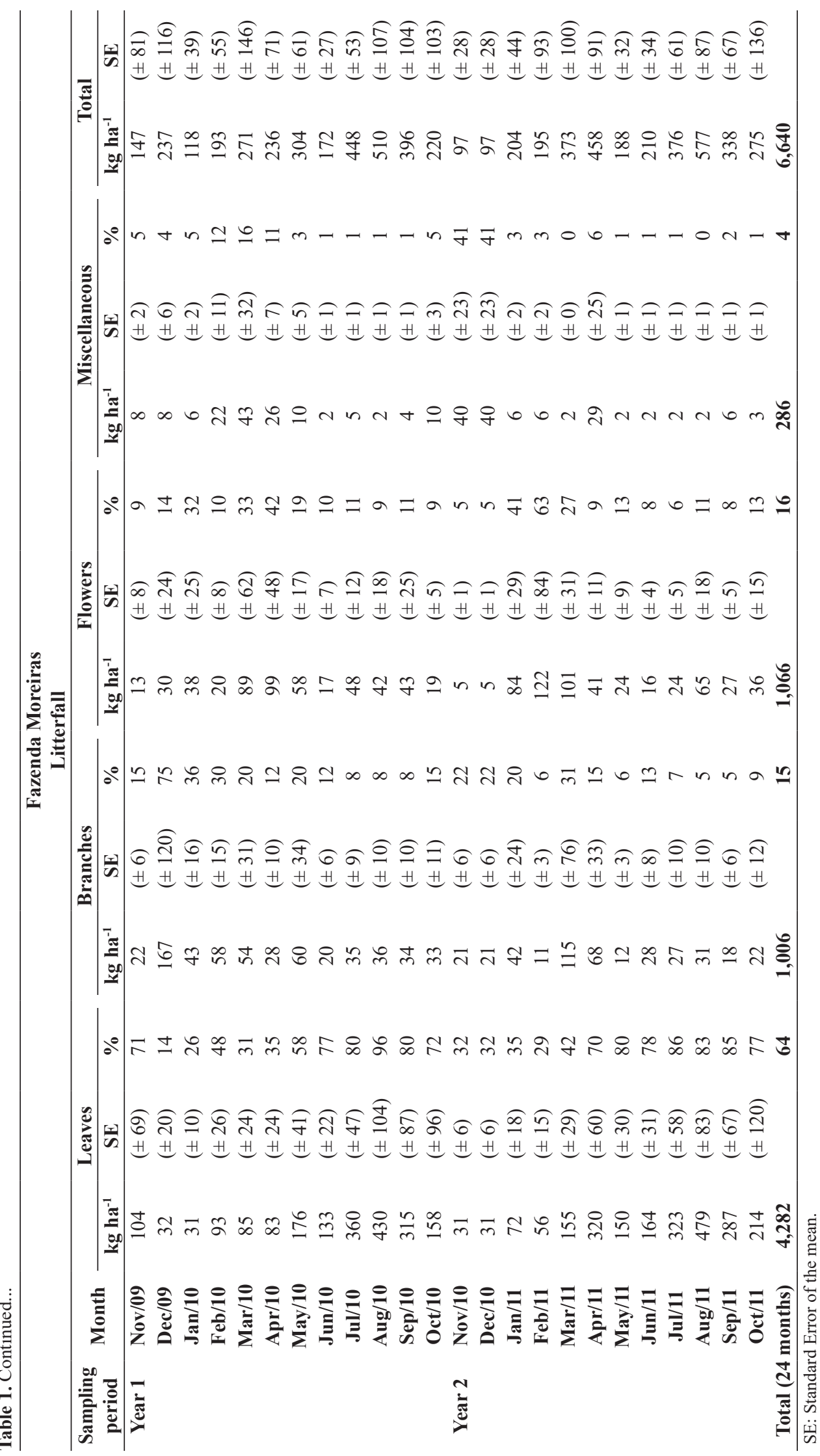


Table 2. Results of repeated measures ANOVA for the monthly and annual variation in litterfall production between November 2009 and October 2011 at RPPN Fazenda Almas, São José dos Cordeiros, and Fazenda Moreiras, São João do Cariri, Paraíba state, Brazil.

\begin{tabular}{|c|c|c|c|c|c|c|c|c|c|c|c|c|}
\hline & \multicolumn{5}{|c|}{ Fazenda Almas } & & \multicolumn{6}{|c|}{ Fazenda Moreiras } \\
\hline & SS & df & MS & $\mathbf{F}$ & $\mathbf{p}$ & & SS & df & MS & $\mathbf{F}$ & $\mathbf{p}$ & \\
\hline Intercept & 6.306 & 1 & 6.306 & 897.271 & 0.000 & * & 3.346 & 1 & 3.346 & 317.294 & 0.000 & * \\
\hline Months & 1.096 & 11 & 0.100 & 14.179 & 0.000 & * & 0.520 & 11 & 0.047 & 4.481 & 0.000 & * \\
\hline Error & 1.265 & 180 & 0.007 & & & & 1.898 & 180 & 0.011 & & & \\
\hline Years & 0.000 & 1 & 0.000 & 0.053 & 0.818 & & 0.007 & 1 & 0.007 & 1.547 & 0.215 & \\
\hline Year $x$ Month & 0.315 & 11 & 0.029 & 7.127 & 0.000 & * & 0.097 & 11 & 0.009 & 1.909 & 0.041 & * \\
\hline Error & 0.723 & 180 & 0.004 & & & & 0.834 & 180 & 0.005 & & & \\
\hline
\end{tabular}

* significant difference with $\mathrm{p}<0.05$. SS: Sum of squares; df: Degrees of freedom; MS: Mean square; F: F-test; p: Statistical significance.

$\left.\mathrm{r}_{\mathrm{s} 120 \text { days }}=0.52, \mathrm{n}=48, \mathrm{p}<0.001\right)$, while evapotranspiration correlated most strongly with rainfall in the second and third months prior to sample collection $\left(\mathrm{r}_{\mathrm{s} 60 \text { days }}=0.53, \mathrm{n}=48\right.$, $\mathrm{p}<0.001 ; \mathrm{r}_{\mathrm{s} 90 \text { days }}=0.53, \mathrm{n}=48, \mathrm{p}<0.001 ; \mathrm{r}_{\mathrm{s} 120 \text { days }}=0.43$, $\mathrm{n}=48, \mathrm{p}<0.005)($ Figure 2A and 2B).

Leaves constituted the predominant fraction of the litterfall, contributing for more than $60 \%$ of the total, while reproductive structures and branches represented approximately $15 \%$ each and miscellaneous materials approximately $3 \%$ (Table 1 ). The leaf fraction of the litterfall correlated most strongly with precipitation (Pp) and actual evapotranspiration (AE) in the fourth and the third months prior to sample collection, respectively (Pp: $\mathrm{r}_{\mathrm{s} 60 \text { days }}=0.28, \mathrm{n}=48, \mathrm{p}>0.05 ; \mathrm{r}_{\mathrm{s} 90 \text { days }}=0.46$, $\mathrm{n}=48, \mathrm{p}<0.005 ; \mathrm{r}_{\mathrm{s} 120 \text { days }}=0.71, \mathrm{n}=48, \mathrm{p}<0.0001$; AE: $\mathrm{r}_{\mathrm{s} 60 \text { days }}=0.53, \mathrm{n}=48, \mathrm{p}<0.0001 ; \mathrm{r}_{\mathrm{s} 90 \text { days }}=0.67$, $\left.\mathrm{n}=48, \mathrm{p}<0.0001 ; \mathrm{r}_{\mathrm{s} 120 \text { days }}=0.62, \mathrm{n}=48, \mathrm{p}<0.0001\right)$. The reproductive structures fraction correlated most strongly with precipitation in the month immediately preceding litterfall collection and with evapotranspiration in the same month of litterfall collection $\left(\mathrm{Pp}: \mathrm{r}_{\mathrm{s} 30 \text { days }}=0.32\right.$, $\mathrm{n}=48, \mathrm{p}<0.05 ; \mathrm{r}_{\mathrm{s} 60 \text { days }}=0.34, \mathrm{n}=48, \mathrm{p}<0.05$; AE: $\mathrm{r}_{\mathrm{s} 30 \text { days }}=0.48, \mathrm{n}=48, \mathrm{p}<0.001 ; \mathrm{r}_{\mathrm{s} 60 \text { days }}=0.26, \mathrm{n}=48$, $\mathrm{p}>0.05)$. The branches fraction presented correlation with precipitation and evapotranspiration only in the month prior the sampling event (Pp: $\mathrm{r}_{\mathrm{s} 60 \text { days }}=0.35, \mathrm{n}=48, \mathrm{p}<0.05$; AE: $\left.\mathrm{r}_{\mathrm{s} 60 \text { days }}=0.38, \mathrm{n}=48, \mathrm{p}<0.05\right)$.

Species richness and density varied from 4 to 22 species (Table 3), and from 199 to 1,648 individuals per ha, respectively. The height varied between 2.8 and $5.1 \mathrm{~m}$, and the mean basal area varied between 0.8 and $19.6 \mathrm{~m}^{2} \mathrm{ha}^{-1}$ (Table 4). Together, the vegetation structure explained $75 \%$ of the annual litterfall production in both localities (Table 5).

\section{Discussion}

The quantities of litterfall deposition observed in this study were within the previously recorded ranges for Seasonally Dry Tropical Forests (Medina and Zelwer, 1972; Gessel et al., 1980; Lugo and Murphy, 1986; Cintrón and Lugo, 1990; Morellato, 1992; Haase and Hirooka, 1998; Saynes et al., 2005). The litterfall production recorded in the drier areas of the Caatinga tends to average between 1,900 and 3,000 $\mathrm{kg} \mathrm{ha}^{-1} \mathrm{yr}^{-1}$ (Santana, 2005; Souto, 2006), but it can reach values about $6,000 \mathrm{~kg} \mathrm{ha}^{-1} \mathrm{yr}^{-1}$ in relatively more humid areas (Sampaio and Silva, 1996; Dantas, 2003; Lopes et al., 2009; Menezes et al., 2012), and even 8,440 $\mathrm{kg} \mathrm{ha}^{-1} \mathrm{yr}^{-1}$ in Piauí (Lima et al., 2015) and 9,160 $\mathrm{kg} \mathrm{ha}^{-1} \mathrm{yr}^{-1}$ in Pernambuco (Santos et al., 2011). The value found for the legally protected area in this study (Fazenda Almas: 4,500 $\mathrm{kg} \mathrm{ha}^{-1} \mathrm{yr}^{-1}$ ) was higher than the obtained for other areas of hyper-xerophytic Caatinga (between 900 and 3,700 $\mathrm{kg} \mathrm{ha}^{-1} \mathrm{yr}^{-1}$ ) with similar amounts of annual precipitation (Santana, 2005; Alves et al., 2006; Souto, 2006; Andrade et al., 2008; Santana and Souto, 2011; Lopes et al., 2015; Silva et al., 2015b). These results indicate that other factors besides precipitation must be influencing litterfall production; including vegetation structure. Climate, topography and edaphic factors are already known to influence the productivity of arid and semiarid ecosystems (Bray and Gorham, 1964; Jaramillo et al., 2011).

In this study, litterfall production presented inter- and intra-annual variation and was correlated with precipitation and evapotranspiration rates. The average annual rainfall is responsible, at least in part, for the variability in primary net productivity between years and consequently, for the variation in litterfall production in both forests (Münster-Swendsen, 1987; Bo Pedersen and Bille-Hansen, 1999) and deserts (Strojan et al., 1979; Lauenroth and Sala, 1992; Alvarez et al., 2009; Campanella and Bertiller, 2010). In the present study, a decrease in litterfall production occurred during the dry season, approximately four months after the highest monthly precipitation rates were recorded. This delayed (two to four months) effect of precipitation and evapotranspiration on litterfall production was consistent with findings for other dry tropical forests, where the highest monthly litterfall production depends on soil water availability, rainfall distribution, natural disturbances and landscape position (Martínez-Yrízar and Sarukhán, 1990; Whigham et al., 1991; Campo and Vázquez-Yanes, 2004; Jaramillo et al., 2011).

Leaves constituted the predominant fraction of the litterfall, accounting for more than $60 \%$ of the total, and this corroborates the results of Bray and Gorham (1964), 
Table 3. List of plant species that occur in sampling points at RPPN Fazenda Almas, São José dos Cordeiros, and Fazenda Moreiras, São João do Cariri, Paraíba state, Brazil.

\begin{tabular}{|c|c|c|c|c|c|c|c|c|c|c|c|c|c|c|c|c|}
\hline \multirow{3}{*}{ Plant species } & \multicolumn{8}{|c|}{ Fazenda Almas } & \multicolumn{8}{|c|}{ Fazenda Moreiras } \\
\hline & \multicolumn{16}{|c|}{$\begin{array}{l}\text { Sampling points } \\
\end{array}$} \\
\hline & $\mathbf{I}$ & II & III & IV & $\mathbf{V}$ & VI & VII & VIII & I & II & III & IV & $\mathbf{V}$ & VI & VII & VIII \\
\hline Allophylus quercifolius (Mart.) Radlk. & & & & $\mathrm{X}$ & $\mathrm{X}$ & & & & & & & & & & & \\
\hline Amburana cearensis (Allemão) A.C.Sm. & & & & $\mathrm{X}$ & & & & & & $\mathrm{X}$ & & & & & & \\
\hline Anadenanthera colubrina (Vell.) Brenan & $\mathrm{X}$ & $\mathrm{X}$ & $\mathrm{X}$ & $\mathrm{X}$ & & $\mathrm{X}$ & $\mathrm{X}$ & $\mathrm{X}$ & $\mathrm{X}$ & & & & & & & \\
\hline Annona leptopetala (R.E.Fr.) H.Rainer & & $\mathrm{X}$ & & & & & $\mathrm{X}$ & & & & $\mathrm{X}$ & & & & & \\
\hline Aspidosperma pyrifolium Mart. \& Zucc & & $\mathrm{X}$ & $\mathrm{X}$ & $\mathrm{X}$ & & $\mathrm{X}$ & $\mathrm{X}$ & $\mathrm{X}$ & $\mathrm{X}$ & $\mathrm{X}$ & $\mathrm{X}$ & $\mathrm{X}$ & $\mathrm{X}$ & $\mathrm{X}$ & $\mathrm{X}$ & $\mathrm{X}$ \\
\hline Bauhinia cheilantha (Bong.) Steud. & $\mathrm{X}$ & $\mathrm{X}$ & $\mathrm{X}$ & $\mathrm{X}$ & & $\mathrm{X}$ & $\mathrm{X}$ & $\mathrm{X}$ & & $\mathrm{X}$ & & $\mathrm{X}$ & & & & \\
\hline Cereus jamacaru DC. & & $\mathrm{X}$ & & & & & & & & & & & & & & \\
\hline Combretum glaucocarpum Mart. & & & & & & & & & & $\mathrm{X}$ & & & & & & \\
\hline Combretum sp.1 & $\mathrm{X}$ & $\mathrm{X}$ & $\mathrm{X}$ & & & $\mathrm{X}$ & $\mathrm{X}$ & $\mathrm{X}$ & & & & & & & & \\
\hline Combretum $\mathrm{sp} .2$ & $\mathrm{X}$ & $\mathrm{X}$ & $\mathrm{X}$ & & & $\mathrm{X}$ & $\mathrm{X}$ & & & & & $\mathrm{X}$ & & & & \\
\hline Commiphora leptophloeos (Mart.) Gillet & & $\mathrm{X}$ & $\mathrm{X}$ & $\mathrm{X}$ & & & & $\mathrm{X}$ & $\mathrm{X}$ & $\mathrm{X}$ & $\mathrm{X}$ & $\mathrm{X}$ & & & & \\
\hline Croton blanchetianus Baill. & & & $\mathrm{X}$ & $\mathrm{X}$ & $\mathrm{X}$ & & $\mathrm{X}$ & $\mathrm{X}$ & & & $\mathrm{X}$ & $\mathrm{X}$ & & & $\mathrm{X}$ & $\mathrm{X}$ \\
\hline Croton echioides Baill. & $\mathrm{X}$ & $\mathrm{X}$ & $\mathrm{X}$ & $\mathrm{X}$ & & $\mathrm{X}$ & $\mathrm{X}$ & $\mathrm{X}$ & & $\mathrm{X}$ & $\mathrm{X}$ & & & & & \\
\hline Cynophalla flexuosa (L.) J.Presl & & & & & $\mathrm{X}$ & & & & $\mathrm{X}$ & & & & & & & \\
\hline Erythrina velutina Willd. & & & $\mathrm{X}$ & & & & & & & & & & & & & \\
\hline Eugenia sp. & & & & & & & & & & $\mathrm{X}$ & & & & & & \\
\hline Helicteres cf. guazumifolia Kunth & $\mathrm{X}$ & & $\mathrm{X}$ & & & & & & & & & & & & & \\
\hline Jatropha mollissima (Pohl) Baill. & $\mathrm{X}$ & $\mathrm{X}$ & $\mathrm{X}$ & $\mathrm{X}$ & $\mathrm{X}$ & $\mathrm{X}$ & $\mathrm{X}$ & $\mathrm{X}$ & $\mathrm{X}$ & $\mathrm{X}$ & $\mathrm{X}$ & & $\mathrm{X}$ & $\mathrm{X}$ & $\mathrm{X}$ & $\mathrm{X}$ \\
\hline Lantana sp. & & & & & & $\mathrm{X}$ & & & & & & & & & $\mathrm{X}$ & \\
\hline Libidibia ferrea (Mart. ex Tul.) L.P. Queiroz & & & & & & & $\mathrm{X}$ & & & & $\mathrm{X}$ & $\mathrm{X}$ & & & $\mathrm{X}$ & \\
\hline Luetzelburgia auriculata (Allemão) Ducke & & & & $\mathrm{X}$ & & & & & & & & & & & & \\
\hline Manihot glaziovii Müll. Arg. & $\mathrm{X}$ & $\mathrm{X}$ & $\mathrm{X}$ & $\mathrm{X}$ & & $\mathrm{X}$ & $\mathrm{X}$ & $\mathrm{X}$ & $\mathrm{X}$ & & $\mathrm{X}$ & & & & & \\
\hline Maytenus rigida Mart. & & & & $\mathrm{X}$ & & & $\mathrm{X}$ & & $\mathrm{X}$ & & & $\mathrm{X}$ & & & & \\
\hline Mimosa ophthalmocentra Mart. ex Benth. & $\mathrm{X}$ & $\mathrm{X}$ & $\mathrm{X}$ & $\mathrm{X}$ & & $\mathrm{X}$ & $\mathrm{X}$ & $\mathrm{X}$ & $\mathrm{X}$ & $\mathrm{X}$ & & $\mathrm{X}$ & $\mathrm{X}$ & $\mathrm{X}$ & & $\mathrm{X}$ \\
\hline Mimosa tenuiflora (Willd.) Poir. & & & $\mathrm{X}$ & & $\mathrm{X}$ & $\mathrm{X}$ & & & & & & & & & & \\
\hline Myracrodruon urundeuva Allemão & $\mathrm{X}$ & $\mathrm{X}$ & $\mathrm{X}$ & $\mathrm{X}$ & & & $\mathrm{X}$ & $\mathrm{X}$ & $\mathrm{X}$ & & $\mathrm{X}$ & $\mathrm{X}$ & & & $\mathrm{X}$ & \\
\hline $\begin{array}{l}\text { Pilosocereus gounellei (F.A.C.Weber) } \\
\text { Byles \& Rowley }\end{array}$ & $\mathrm{X}$ & & & & & & & & & $\mathrm{X}$ & & & & & & \\
\hline Piptadenia stipulacea (Benth.) Ducke & & & $\mathrm{X}$ & & $\mathrm{X}$ & & $\mathrm{X}$ & & & & & $\mathrm{X}$ & & & & \\
\hline Pisonia sp. & $\mathrm{X}$ & & & $\mathrm{X}$ & & & & & & & & $\mathrm{X}$ & & & & \\
\hline Poincianella pyramidalis (Tul.) L.P.Queiroz & $\mathrm{X}$ & $\mathrm{X}$ & $\mathrm{X}$ & $\mathrm{X}$ & $\mathrm{X}$ & $\mathrm{X}$ & $\mathrm{X}$ & $\mathrm{X}$ & $\mathrm{X}$ & $\mathrm{X}$ & $\mathrm{X}$ & $\mathrm{X}$ & $\mathrm{X}$ & $\mathrm{X}$ & $\mathrm{X}$ & $\mathrm{X}$ \\
\hline $\begin{array}{l}\text { Pseudobombax marginatum (A.St.-Hil., } \\
\text { Juss. \& Cambess.) A.Robyns }\end{array}$ & & & & $\mathrm{X}$ & & & & & & $\mathrm{X}$ & & & & & & \\
\hline Sapium glandulosum (L.) Morong & $\mathrm{X}$ & & & $\mathrm{X}$ & & & $\mathrm{X}$ & & & & & & & & & \\
\hline Schinopsis brasiliensis Engl. & & & $\mathrm{X}$ & & & & & & $\mathrm{X}$ & & $\mathrm{X}$ & & & & & \\
\hline $\begin{array}{l}\text { Sideroxylon obtusifolium (Roem. \& } \\
\text { Schult.) T.D.Penn. }\end{array}$ & & & & & & & & & & & $\mathrm{X}$ & & & & & \\
\hline Spondias tuberosa Arruda & $\mathrm{X}$ & $\mathrm{X}$ & & & & & $\mathrm{X}$ & $\mathrm{X}$ & & & $\mathrm{X}$ & & & & & \\
\hline Varronia polycephala Lam. & & & & & & & & & $\mathrm{X}$ & & & & & & $\mathrm{X}$ & \\
\hline Ziziphus joazeiro Mart. & & & $\mathrm{X}$ & & $\mathrm{X}$ & & & & & & $\mathrm{X}$ & & & & $\mathrm{X}$ & \\
\hline Indeterminado 1 & & & $\mathrm{X}$ & $\mathrm{X}$ & & & $\mathrm{X}$ & & & & & & & & & \\
\hline Indeterminado 2 & $X$ & & $\mathrm{X}$ & & & & & & & & & & & & & \\
\hline Indeterminado 3 & & & $\mathrm{X}$ & & & & & & & & & & & & & \\
\hline Indeterminado 4 & & & & & & $\mathrm{X}$ & & & & & & & & & & \\
\hline Indeterminado 5 & & & & & & & & $\mathrm{X}$ & & & & & & & & \\
\hline Indeterminado 6 & & & & & & & $\mathrm{X}$ & $\mathrm{X}$ & & & & & & & & \\
\hline Indeterminado 7 (Capparaceae) & & & & & $\mathrm{X}$ & $\mathrm{X}$ & & & & & $\mathrm{X}$ & & & & $\mathrm{X}$ & \\
\hline Indeterminado 8 (Fabaceae) & & & & & & & & & & & $\mathrm{x}$ & & & & & \\
\hline
\end{tabular}


Table 4. Litterfall production and vegetation structure from November 2009 to October 2011 at RPPN Fazenda Almas, São José dos Cordeiros, and Fazenda Moreiras, São João do Cariri, Paraíba state, Brazil.

\begin{tabular}{|c|c|c|c|c|c|c|c|c|c|c|c|c|c|c|c|c|}
\hline & \multicolumn{8}{|c|}{ Fazenda Almas } & \multicolumn{8}{|c|}{ Fazenda Moreiras } \\
\hline & \multicolumn{16}{|c|}{ Sampling points } \\
\hline & I & II & III & IV & $\mathbf{V}$ & VI & VII & VIII & I & II & III & IV & V & VI & VII & VIII \\
\hline $\begin{array}{l}\text { Litterfall } \\
\left(\mathrm{kg} \mathrm{ha}^{-1}\right)\end{array}$ & 6,000 & 4,900 & 5,900 & 4,800 & 4,600 & 2,100 & 5,500 & 2,600 & 3,900 & 3,500 & 7,000 & 3,800 & 1,600 & 2,100 & 900 & 3,400 \\
\hline $\begin{array}{l}\text { Individuals } \\
\text { (number) }\end{array}$ & 143 & 125 & 194 & 148 & 86 & 145 & 159 & 109 & 207 & 184 & 96 & 102 & 149 & 85 & 25 & 75 \\
\hline $\begin{array}{l}\text { Density } \\
\left(\text { ind ha' } \mathbf{h a}^{-1}\right)\end{array}$ & 1,139 & 1,011 & 1,377 & 1,178 & 685 & 1,154 & 1,266 & 860 & 1,648 & 1,465 & 764 & 812 & 1,186 & 677 & 199 & 597 \\
\hline $\begin{array}{l}\text { Species } \\
\text { richness }\end{array}$ & 16 & 15 & 22 & 19 & 9 & 14 & 20 & 15 & 12 & 12 & 17 & 12 & 4 & 4 & 10 & 5 \\
\hline Height (m) & 4.3 & 4.0 & 3.4 & 3.3 & 3.9 & 3.2 & 4.4 & 3.2 & 4.0 & 3.5 & 4.9 & 4.4 & 3.1 & 2.8 & 3.1 & 5.1 \\
\hline $\begin{array}{l}\text { Basal area } \\
\left(\mathrm{m}^{2} \mathrm{ha}^{-1}\right)\end{array}$ & 6.0 & 8.5 & 7.1 & 6.1 & 4.9 & 4.5 & 19.6 & 3.7 & 5.7 & 8.0 & 13.2 & 5.3 & 3.2 & 3.0 & 0.8 & 1.8 \\
\hline
\end{tabular}

Table 5. General Linear Models (GLM) to evaluate the relationship between spatial variability of litter production and vegetation structure at RPPN Fazenda Almas, São José dos Cordeiros, and Fazenda Moreiras, São João do Cariri, Paraíba state, Brazil.

\begin{tabular}{|c|c|c|c|c|c|c|}
\hline & SS & df & MS & $\mathbf{F}$ & p & \\
\hline Intercept & 1,296 & 1 & 1,296 & 11,218 & 0.006 & $*$ \\
\hline Density (ind ha-1) & 1,818 & 1 & 1,818 & 15,744 & 0.002 & * \\
\hline Species richness & 0.668 & 1 & 0.668 & 5,788 & 0.035 & $*$ \\
\hline Height (m) & 0.046 & 1 & 0.046 & 0.397 & 0.541 & \\
\hline Basal area $\left(\mathrm{m}^{2} \mathrm{ha}-1\right)$ & 0.021 & 1 & 0.021 & 0.183 & 0.677 & \\
\hline Error & 1,270 & 11 & 0.115 & & & \\
\hline
\end{tabular}

*significant difference with $\mathrm{p}<0.05$. SS: Sum of squares; df: Degrees of freedom; MS: Mean Square; F: F-test; p: Statistical significance.

who found that leaves constitute $58 \%$ to $79 \%$ of the organic material deposited in the soil in different macroecological zones. In areas with Caatinga vegetation, the leaf fraction has been observed to vary from $56.2 \%$ to $80.6 \%$ (Santana, 2005; Alves et al., 2006; Souto, 2006; Costa et al., 2007; Andrade et al., 2008; Lopes et al., 2009; Costa et al., 2010; Lopes et al., 2015; Silva et al., 2015b). Reproductive structures and branches represented approximately 15\% of the total litterfall in this study. Martínez-Yrízar and Sarukhán (1990) reported a 17\% contribution from the branch fraction in a deciduous forest in Mexico, which was very similar to the value observed by Santos et al. (2011) in the Caatinga in Pernambuco, and Lopes et al. (2015) in Rio Grande do Norte, Brazil.

The deposition of the leaf fraction was best explained by precipitation and evapotranspiration in the fourth and third months prior to the collecting events. The loss of leaves by the vegetation is due to natural senescence and the mechanical action of rain (Toledo, 2003) as well as the deciduous behavior of most Caatinga species (Souto, 2006). The deposition of reproductive structures was correlated with precipitation and evapotranspiration in the month preceding sampling as well as with the phenology of the dominant species (Lampe et al., 1992; Martínez-Yrízar et al., 1999; Alvarez et al., 2009). The peak of reproductive structures in the litterfall during the rainy season observed in this study agreed with the findings of Quirino (2006), who reported that most individuals at RPPN Fazenda Almas were developing flower buds during this period. Studies in other tropical regions have also indicated that a greater number of species present flower buds during the wet season (Talora and Morellato, 2000; Zipparro, 2004).

The variation in litterfall production rates between the study areas resulted, at least in part, from the effects of species richness, density, average height and basal area of the woody species. It is known that litterfall production is related to vegetation structure (Schlittler et al., 1993; Werneck et al., 2001), age (Leitão-Filho et al., 1993) and floristic composition (Sundarapandian and Swamy, 1999), but the degree of influence of each factor depends on the unique characteristics of each plant community (Pires et al., 2006). According to Delitti (1989), litterfall composition also varies according to the ecosystem and its successional stage. Therefore, the litterfall production in the study areas reflected the characteristics of each habitat (such as the presence of mountainous areas and the proximity to rocky outcrops or temporary water courses) and the different land-use histories. 
Biodiversity loss, especially of large tree species, and the predominance of a few species in sites previously used for agriculture and livestock are characteristics of Caatinga ecosystems (Pereira et al., 2001; Pereira et al., 2003; Alves et al., 2009). In this study, the woody vegetation structure accounted for $75 \%$ of the litterfall production, which indicates that disturbances that interfere with the Caatinga structure can affect litterfall production and, consequently, the dynamics of nutrient cycling. Several authors have proposed that woody species promote soil heterogeneity through the differential accumulation of litterfall under their canopies, thus acting as "ecosystem engineers" (Schlesinger, 1997; Reynolds et al., 1999). There is evidence that climatic seasonality and microhabitat heterogeneity greatly influence plant biological cycles and the dynamics of plant populations in the Caatinga (Araújo, 2005; Lima et al., 2007).

In conclusion, climatic factors (precipitation and evapotranspiration) indirectly influence the annual rate of litterfall production in the semi-arid region of Northeastern Brazil, since they directly influence the species and the structure of the vegetation in the region. Sites with greater plant density and species richness, as well as taller individuals and greater basal areas and, thus, greater aerial biomass produce greater amounts of litterfall. Plant cover also influences quantitatively and qualitatively litterfall production throughout the year because this process is directly related to plant phenology. Therefore, climate and vegetation structure affect the temporal and spatial dynamics of litterfall production in the Caatinga and consequently influence the return of nutrients to the soil. Thus, the pathways of nutrient transfer from plants to the soil in the Caatinga are closely associated with climatic and phenological factors (Schumacher, 1992; Poggiani and Schumacher, 2000; Santana, 2005; Souto, 2006) as well as with environmental aspects such as the preservation status and land-use history of an area. Knowledge about these pathways is highly important, both for understanding ecosystem function and for improving forest management practices and restoration of degraded areas (Souza and Davide, 2001). So, data on nutrient cycling in the Caatinga are fundamental for the conservation of its biodiversity and for the design of adequate management plans for this ecosystem.

\section{Acknowledgements}

The authors thank the Braz and Maracajá families, owners of Fazenda Almas and Fazenda Moreiras, for research permits and logistical support during the field work. We also thank all who helped during the fieldwork, as well as F. Luizão and E. Sampaio for their contributions to the manuscript. We also thank Coordination of Improvement of Higher Education Personne (CAPES/UFPB) for the fellowships granted to V.F.P.A., and CNPq (Brazilian National Council for Scientific and Technological Development) for financial support through both PELD - Caatinga Project (520062/2006-0) and Universal Project (478449/2009-7).

\section{References}

ALBURQUEQUE, A.W., FILHO, G.M., SANTOS, J.R., COSTA, J.P.V. and SOUZA, J.L., 2005. Determinação de fatores da equação universal de perda de solo em Sumé, PB. Revista Brasileira de Engenharia Agrícola e Ambiental, vol. 9, no. 2, pp. 153-160. http://dx.doi.org/10.1590/S1415-43662005000200001.

ALVAREZ, J.A., VILLAGRA, P.E., ROSSI, B.E. and CESCA, E.M., 2009. Spatial and temporal litterfall heterogeneity generated by woody species in the Central Monte desert. Plant Ecology, vol. 205 , no. 2 , pp. $295-303$. http://dx.doi.org/10.1007/s11258009-9618-z.

ALVES, A.R., SOUTO, J.S., SOUTO, P.C. and HOLANDA, A.C., 2006. Aporte e decomposição de serrapilheira em área de Caatinga, na Paraíba. Revista de Biologia e Ciências da Terra, vol. 6, no. 2, pp. 194-203.

ALVES, J.J.A., ARAÚJO, M.A. and NASCIMENTO, S.S., 2009. Degradação da Caatinga: uma investigação ecogeográfica. Revista Caatinga, vol. 22, no. 3, pp. 126-135.

ANDRADE-LIMA, D., 1981. The caatingas dominium. Revista Brasileira de Botanica. Brazilian Journal of Botany, vol. 4, no. 2, pp. 149-163.

ANDRADE, R.L., SOUTO, J.S., SOUTO, P.C. and BEZERRA, D.M., 2008. Deposição de serrapilheira em área de Caatinga na RPPN "Fazenda Tamanduá", Santa Terezinha-PB. Revista Caatinga, vol. 21, no. 2, pp. 223-230.

ARAÚJO, E.L. 2005. Estresses abióticos e bióticos como forças modeladoras da dinâmica de populações vegetais da caatinga. In: R.J.M. Nogueira, E.L. Araújo, L.G. Willadino and U.M.T. Cavalcante, eds. Estresses ambientais: danos e beneficios em plantas. Recife: Imprensa Universitária/UFRPE, pp. 50-64.

ARCHER, S., SCIFRES, C., BASSHAM, C.R. and MAGGIO, R., 1988. Autogenic succession in a subtropical savanna: conversion of grassland to thorn woodland. Ecological Monographs, vol. 58, no. 2, pp. 111-127. http://dx.doi.org/10.2307/1942463.

BARBOSA, M.R.V., LIMA, I.B., LIMA, J.R., CUNHA, J.P., AGRA, M.F. and THOMAS, W.W., 2007. Vegetação e flora no Cariri Paraibano. Oecologia Brasiliensis, vol. 11, no. 3, pp. 313322. http://dx.doi.org/10.4257/oeco.2007.1103.01.

BAUER, D., SANTOS, E.L. and SCHMITT, J.L., 2016. Avaliação da decomposição de serapilheira em dois fragmentos de Caatinga no sertão Paraibano. Pesquisas. Botânica, vol. 69, pp. 307-318.

BISIGATO, A.J., VILLAGRA, P.E., ARES, J.O. and ROSSI, B.E., 2009. Vegetation heterogeneity in Monte Desert ecosystems: A multi-scale approach linking patterns and processes. Journal of Arid Environments, vol. 73, no. 2, pp. 182-191. http://dx.doi. org/10.1016/j.jaridenv.2008.09.001.

BO PEDERSEN, L. and BILLE-HANSEN, J., 1999. A comparison of litterfall and element fluxes in even aged Norway spruce, sitka spruce and beech stands in Denmark. Forest Ecology and Management, vol. 114, no. 1, pp. 55-70. http://dx.doi.org/10.1016/ S0378-1127(98)00381-8.

BRAY, J.R. and GORHAM, E., 1964. Litter production in forests of the world. In: J.B. Cragg, ed. Advances in Ecological Research. 
London: New York: Academic Press, pp. 101-157. https://doi. org/10.1016/S0065-2504(08)60331-1.

BÚRQUEZ, A., MARTÍNEZ-YRÍZAR, A. and NÚÑEZ, S., 1999. Sonoran Desert productivity and the effect of trap size on litterfall estimates in dryland vegetation. Journal of Arid Environments, vol. 43, no. 4, pp. 459-465. http://dx.doi.org/10.1006/jare.1999.0547.

CAMPANELLA, M.V. and BERTILLER, M.B., 2010. Leaf litterfall patterns of perennial plant species in the arid Patagonian Monte, Argentina. Plant Ecology, vol. 210, no. 1, pp. 43-52. http:// dx.doi.org/10.1007/s11258-010-9736-7.

CAMPO, J. and VÁZQUEZ-YANES, C., 2004. Effects of nutrient limitation on aboveground carbon dynamics during Tropical Dry Forest regeneration in Yucatán, Mexico. Ecosystems, vol. 7, no. 3, pp. 311-319. http://dx.doi.org/10.1007/s10021-003-0249-2.

CARVALHO, F.A.F. and CARVALHO, M.G.F., 1985. Vegetação. In: GOVERNO DO ESTADO DA PARAÍBA, SECRETARIA DE EDUCAÇÃO AND UNIVERSIDADE FEDERAL DA PARAÍBA, eds. Atlas Geográfico do Estado da Paraíba. João Pessoa: Grafset, pp. 34-43.

CINTRÓN, B.B. and LUGO, A.E., 1990. Litter fall in a subtropical dry forest: Guánica, Puerto Rico. Acta Científica, vol. 4, pp. 37-49.

COSTA, C.C.A., CAMACHO, R.G.V., MACEDO, I.D. and SILVA, P.C.M., 2010. Análise comparativa da produção de serapilheira em fragmentos arbóreos e arbustivos em área de caatinga na flona de Açu-RN. Revista Árvore, vol. 34, no. 2, pp. 259-265. http://dx.doi.org/10.1590/S0100-67622010000200008.

COSTA, C.C.A., DANTAS, I.M., CAMACHO, R.G.V., SOUZA, A.M. and SILVA, N.F., 2007. Produção de serapilheira na Caatinga da Floresta Nacional do Açú-RN. Revista Brasileira de Biociências, vol. 5, pp. 246-248.

DANTAS, J.S., 2003. Dinâmica da produção e decomposição de folhedo e ciclagem de nutrientes em um ecossistema de caatinga arbórea no Agreste da Paraíba. Areia: Universidade Federal da Paraíba, 37 p. Monografia de Graduação em Agronomia.

DELITTI, W.B.C., 1989. Ciclagem de nutrientes minerais em matas ciliares. In: L.M. BARBOSA, coord. Simpósio sobre Mata Ciliar: Campinas: Fundação Cargill, pp. 88-98.

DIRZO, R., YOUNG, H.S., MOONEY, H.A. and CEBALLOS, G., 2011. Seasonally dry tropical forests: ecology and conservation. 1 st ed. Washington: Island Press/Center for Resource Economics, 394 p. http://dx.doi.org/10.5822/978-1-61091-021-7.

FACELLI, J.M. and PICKETT, S.T.A., 1991. Plant litter: Its dynamics and effects on plant community structure. Botanical Review, vol. 57, no. 1, pp. 1-32. http://dx.doi.org/10.1007/ BF02858763.

GESSEL, S.P., COLE, D.W., JOHNSON, D. and TURNER, J., 1980. The nutrient cycles of two Costa Rican forests. In: V.P. Agarwal and V.K. Sharma, eds. Progress in ecology. New Delhi: Today and Tomorrow's Printers and Publishers, pp. 23-44.

GONZÁLEZ-RODRÍGUEZ, H., DOMÍNGUEZ-GÓMEZ, T.G., CANTÚ-SILVA, I., GÓMEZ-MEZA, M.V., RAMÍREZLOZANO, R.G., PANDO-MORENO, M. and FERNÁNDEZ, C.J., 2011. Litterfall deposition and leaf litter nutrient return in different locations at Northeastern Mexico. Plant Ecology, vol. 212 , no. 10 , pp. $1747-1757$. http://dx.doi.org/10.1007/s11258011-9952-9.

HAASE, R. and HIROOKA, R.Y., 1998. Structure, composition and small litter dynamics of a semi-deciduous forest in Mato
Grosso, Brazil. Flora, vol. 193, no. 2, pp. 141-147. http://dx.doi. org/10.1016/S0367-2530(17)30830-7.

JARAMILLO, V.J., MARTÍNEZ-YRÍZAR, A. and SANFORD, R.L. 2011. Primary productivity and biogeochemistry of Seasonally Dry Tropical Forests. In: R. Dirzo, H.S. Young, H.A. Mooney and G. Ceballos, eds. Seasonally dry tropical forests: Ecology and conservation. Washington: Island Press/Center for Resource Economics, pp. 109-128. http://dx.doi.org/10.5822/978-1-61091021-7_7.

LAMPE, M.G., BERGERON, Y., MCNEIL, R. and LEDUC, A., 1992. Seasonal flowering and fruiting patterns in tropical semi-arid vegetation of Northeastern Venezuela. Biotropica, vol. 24, no. 1, pp. 64-76. http://dx.doi.org/10.2307/2388474.

LAUENROTH, W.K. and SALA, O.E., 1992. Long-term forage production of North American Shortgrass Steppe. Ecological Applications, vol. 2, no. 4, pp. 397-403. http://dx.doi. org/10.2307/1941874. PMid:27759270.

LEITÃO-FILHO, H.F., PAGANO, S.N., CÉSAR, O., TIMONI, J.L. and RUEDA, J.J. 1993. Aspectos da ciclagem de nutrientes. In: H.F. LEITÃO-FILHO, ed. Ecologia da Mata Atlântica em Cubatão. São Paulo: UNESP-UNICAMP, pp. 129-163.

LIMA, E.N., ARAÚJO, E.L., SAMPAIO, E.V.S.B., FERRAZ, E.M.N., SILVA, K.A. and PIMENTEL, R.M.M., 2007. Fenologia e dinâmica de duas populações herbáceas da Caatinga. Revija za Geografijo, vol. 24, no. 1, pp. 120-136.

LIMA, R.P., FERNANDES, M.M., FERNANDES, M.R.M. and MATRICARDI, E.A.T., 2015. Aporte e decomposição da serapilheira na Caatinga no sul do Piauí. Floresta e Ambiente, vol. 22, no. 1, pp. 42-49. http://dx.doi.org/10.1590/2179-8087.062013.

LOPES, J.F.B., ANDRADE, E.M., LOBATO, F.A.O., PALÁCIO, H.A.Q. and ARRAES, F.D.D., 2009. Deposição e decomposição de serapilheira em área da Caatinga.Agro@mbiente.Online, vol. 3, no. 2, pp. 72-79. http://dx.doi.org/10.18227/1982-8470ragro. v3i2.252.

LOPES, M.C.A., ARAÚJO, V.F.P. and VASCONCELLOS, A., 2015. The effects of rainfall and vegetation on litterfall production in the semiarid region of northeastern Brazil. Brazilian Journal of Biology $=$ Revista Brasileira de Biologia, vol. 75, no. 3, pp. 703708. http://dx.doi.org/10.1590/1519-6984.21613. PMid:26421774.

LUGO, A.E. and MURPHY, P.G., 1986. Nutrient dynamics of a Puerto Rican Subtropical Dry Forest. Journal of Tropical Ecology, vol. 2, no. 1, pp. 55-72. http://dx.doi.org/10.1017/ S0266467400000602.

MARTÍNEZ-YRÍZAR, A. and SARUKHÁN, J., 1990. Litterfall patterns in a tropical deciduous forest in Mexico over a five-year period. Journal of Tropical Ecology, vol. 6, no. 4, pp. 433-444. http://dx.doi.org/10.1017/S0266467400004831.

MARTÍNEZ-YRÍZAR, A., NÚÑEZ, S., MIRANDA, H. and BÚRQUEZ, A., 1999. Temporal and spatial variation of litter production in Sonoran Desert communities. Plant Ecology, vol. 145, no. 1, pp. 37-48. http://dx.doi.org/10.1023/A:1009896201047.

MEDEIROS, P.H.A., ARAÚJO, J.C. and BRONSTERT, A., 2009. Interception measurements and assessment of Gash model performance for a tropical semi-arid region. Ciência Agronômica, vol. 40 , no. 2 , pp. $165-174$.

MEDINA, E. and ZELWER, M. 1972. Soil respiration in tropical plant communities. In: P.M. Golley and F.B. Golley, eds. Tropical ecology with an emphasis on organic production. Athens: University of Georgia, pp. 245-269. 
MENEZES, R.S.C., SAMPAIO, E.V.S.B., GIONGO, V. and PÉREZ-MARIN, A.M., 2012. Biogeochemical cycling in terrestrial ecosystems of the Caatinga Biome. Brazilian Journal of Biology = Revista Brasileira de Biologia, vol. 72, no. 3, suppl, pp. 643-653. http://dx.doi.org/10.1590/S1519-69842012000400004. PMid:23011295.

MORELLATO, L.P.C., 1992. Nutrient cycling in two South-East brazilian forests. 1 Litterfall and litter standing crop. Journal of Tropical Ecology, vol. 8, no. 2, pp. 205-215. http://dx.doi. org/10.1017/S0266467400006362.

MÜNSTER-SWENDSEN, M., 1987. The effect of precipitation on radial increment in Norway Spruce (Picea abies Karst.) and on the dynamics of a lepidopteran pest insect. Journal of Applied Ecology, vol. 24 , no. 2 , pp. 563-571. http://dx.doi.org/10.2307/2403893.

PEREIRA, I.M., ANDRADE, L.A., COSTA, J.R.M. and DIAS, J.M., 2001. Regeneração natural em um remanescente de caatinga sob diferentes níveis de perturbação, no agreste paraibano. Acta Botanica Brasílica, vol. 15, no. 3, pp. 413-426. http://dx.doi. org/10.1590/S0102-33062001000300010.

PEREIRA, I.M., ANDRADE, L.A., SAMPAIO, E.V.S.B. and BARBOSA, M.R.V., 2003. Use-history effects on structure and flora of Caatinga. Biotropica, vol. 35, no. 2, pp. 154-165. http:// dx.doi.org/10.1111/j.1744-7429.2003.tb00275.x.

PIRES, L.A., BRITEZ, R.M., MARTEL, G. and PAGANO, S.N., 2006. Produção, acúmulo e decomposição da serapilheira em uma restinga da Ilha do Mel, Paranaguá, PR, Brasil. Acta Botanica Brasílica, vol. 20, no. 1, pp. 173-184. http://dx.doi. org/10.1590/S0102-33062006000100016.

POGGIANI, F. and SCHUMACHER, M.V., 2000. Ciclagem de nutrientes em florestas nativas. In: J.L.M. Gonçalves and V. Benedetti, eds. Nutrição e Fertilização Florestal. Piracicaba: IPEF, pp. 288-308.

PRADO, D.E. and GIBBS, P.E., 1993. Patterns of species distributions in the Dry Seasonal Forests of South America. Annals of the Missouri Botanical Garden, vol. 80, no. 4, pp. 902-927. http://dx.doi.org/10.2307/2399937.

PROCTOR, J., ANDERSON, J.M., FOGDEN, S.C.L. and VALLACK, H.W., 1983. Ecological studies in four contrasting lowland rain forests in Gunung Mulu National Park, Sarawak: 2. Litterfall, litter standing crop and preliminary observations on herbivory. Journal of Ecology, vol. 71, no. 1, pp. 261-283. http:// dx.doi.org/10.2307/2259976.

PROGRAMA DE MONITORAMENTO CLIMÁTICO EM TEMPO REAL DA REGIÃO NORDESTE - PROCLIMA, 2011 [viewed 11 December 2011]. [online]. Available from: http://www6. cptec.inpe.br/proclima2/balanco_hidrico/balancohidrico.shtml

QUIRINO, Z.G.M., 2006. Fenologia, sindromes de polinização e dispersão e recursos florais de uma comunidade de caatinga no Cariri Paraibano. Recife: Universidade Federal do Pernambuco. 153 p. Tese de Doutorado em Biologia Vegetal.

REIS, A.C.S., 1976. Clima da Caatinga. Anais da Academia Brasileira de Ciências, vol. 48, no. 2, pp. 325-335.

REYNOLDS, J.F., VIRGÍNIA, R.A., KEMP, P.R., SOYZA, A.G. and TREMMEL, D.C., 1999. Impact of drought on desert shrubs: Effects of seasonality and degree of resource island development. Ecological Monographs, vol. 69, no. 1, pp. 69-106. http://dx.doi. org/10.1890/0012-9615(1999)069[0069:IODODS]2.0.CO;2.

SAMPAIO, E.V.S.B., ANDRADE-LIMA, D. and GOMES, M.A.F., 1981. O gradiente vegetacional das caatingas e áreas anexas. Revista Brasileira de Botanica. Brazilian Journal of Botany, vol. 4, no. 1, pp. 27-30.

SAMPAIO, E.V.S.B., 1995. Overview of the Brazilian Caatinga. In: S.H. Bullock, H. Mooney and E. Medina, eds. Seasonally dry tropical forests. Cambridge: Cambridge University Press, pp. 35-63. http://dx.doi.org/10.1017/CBO9780511753398.003.

SAMPAIO, E.V.S.B. and SILVA, G.C., 1996. Ciclagem de nutrientes. In: E.V.S.B. Sampaio, S.J. Mayo and M.R.V. Barbosa, eds. Pesquisa botânica nordestina: progresso e perspectivas. Recife: Sociedade Botânica do Brasil - Seção Regional de Pernambuco, pp. 191-202.

SANTANA, J.A.S., 2005. Estrutura fitossociológica, produção de serapilheira e ciclagem de nutrientes em uma área de caatinga no Seridó do Rio Grande do Norte. Areia: Universidade Federal da Paraíba, 184 p. Tese de Doutorado em Agronomia.

SANTANA, J.A.S. and SOUTO, J.S., 2011. Produção de serapilheira na Caatinga da região semi-árida do Rio Grande do Norte, Brasil. Idesia, vol. 29, no. 2, pp. 87-94. http://dx.doi. org/10.4067/S0718-34292011000200011.

SANTOS, P.S., SOUZA, J.T., SANTOS, J.M.F.F., SANTOS, D.M. and ARAÚJO, E.L., 2011. Diferenças sazonais no aporte de serrapilheira em uma área de caatinga em Pernambuco. Revista Caatinga, vol. 24, no. 4, pp. 94-101.

SAYNES, V., HIDALGO, C., ETCHEVERS, J.D. and CAMPO, J.E., 2005. Soil $\mathrm{C}$ and $\mathrm{N}$ dynamics in primary and secondary seasonally dry tropical forests in Mexico. Applied Soil Ecology, vol. 29, no. 3, pp. 282-289. http://dx.doi.org/10.1016/j. apsoil.2004.11.007.

SCHLESINGER, W.H. 1997. Biogeochemistry: An analysis of global change. 2nd ed. San Diego: Gulf Professional Publishing. $588 \mathrm{p}$.

SCHLITTLER, F.H.M., MARINIS, G. and CESAR, O., 1993. Producão de serapilheira na floresta do Morro do Diabo, Pontal do Paranapanema - SP. Naturalia, vol. 18, no. 12, pp. 135-147.

SCHUMACHER, M.V., 1992. Aspectos da ciclagem de nutrientes e do microclima em talhões de Eucalyptus camadulensis Dehnh, Eucalyptus grandis Hill ex Maiden e Eucalyptus torelliana F. Muell. Piracicaba: Universidade de São Paulo, 87 p. Dissertação de Mestrado em Ciências Florestais.

SHEPHERD, G.J., 2008. Fitopac 2.0: manual do usuário. Campinas: Departamento de Botânica, Universidade Estadual de Campinas - UNICAM.

SILVA, A.M., SILVA, R.M. and SILVA, B.B., 2015a. Determinação de temperatura da superfície e estimativa do saldo de radiação e evapotranspiração usando imagens LANDSAT e dados observados. Revista Brasileira de Cartografia, vol. 67, no. 6, pp. 1203-1216.

SILVA, V.N., SOUTO, L.S., DUTRA FILHO, J.A., SOUZA, T.M.A. and BORGES, C.H.A., 2015b. Deposição de serapilheira em uma área de caatinga preservada no semiárido da Paraíba, Brasil. Revista Verde de Agroecologia e Desenvolvimento Sustentável, vol. 10, no. 2, pp. 21-25. http://dx.doi.org/10.18378/rvads.v10i2.3409.

SOUTO, P.C., 2006. Acumulação e decomposição da serapilheira e distribuição de organismos edáficos em área de caatinga na Paraíba, Brasil. Areia: Universidade Federal da Paraíba Tese de Doutorado. 146 p. Tese de Doutorado em Agronomia.

SOUZA, J.A. and DAVIDE, A.C., 2001. Deposição de serapilheira e nutrientes em uma mata não minerada e em plantações de 
bracatinga (Mimosa scabrella) e de eucalipto (Eucalyptus saligna) em áreas de mineração de bauxita. Cerne, vol. 7, no. 1, pp. 101-114.

STATSOFT, I.N.C., 1995. Statistics. Version 5.0. Tulsa: StatSoft.

STROJAN, C.L., TURNER, F.B. and CASTETTER, R., 1979. Litter fall from shrubs in the Northern Mojave Desert. Ecology, vol. 60, no. 5, pp. 891-900. http://dx.doi.org/10.2307/1936857.

SUNDARAPANDIAN, S.M. and SWAMY, P.S., 1999. Litter production and leaf-litter decomposition of selected tree species in tropical forests at Kodayar in the Western Ghats, India. Forest Ecology and Management, vol. 123, no. 2-3, pp. 231-244. http:// dx.doi.org/10.1016/S0378-1127(99)00062-6.

TALORA, D.C. and MORELLATO, P.C., 2000. Fenologia de espécies arbóreas em floresta de planície litorânea do Sudeste do Brasil. Revista Brasileira de Botanica. Brazilian Journal of Botany, vol. 23, no. 1, pp. 13-26. http://dx.doi.org/10.1590/ S0100-84042000000100002.

TOLEDO, L.O., 2003. Aporte de serrapilheira, fauna edáfica e taxa de decomposição em áreas de floresta secundária no municipio de Pinheiral, RJ. Seropédica: Universidade Federal Rural do Rio de Janeiro. 80 p. Dissertação de Mestrado em em Ciências Ambientais e Florestais.

VASCONCELOS, H.L. and LUIZÃO, F.J., 2004. Litter production and litter nutrient concentrations in a fragmented amazonian landscape. Ecological Applications, vol. 14, no. 3, pp. 884-892. http://dx.doi.org/10.1890/03-5093.

VITAL, A.R.T., GUERRINI, I.A., FRANKEN, W.K. and FONSECA, R.C.B., 2004. Produção de serapilheira e ciclagem de nutrientes de uma floresta estacional semidecidual em zona ripária. Revista Árvore, vol. 28, no. 6, pp. 793-800. http://dx.doi. org/10.1590/S0100-67622004000600004.

VITOUSEK, P.M., 1984. Litterfall, nutrient cycling, and nutrient limitation in tropical forests. Ecology, vol. 65, no. 1, pp. 285-298. http://dx.doi.org/10.2307/1939481.

WERNECK, M.S., PEDRALLI, G. and GIESEKE, L.F., 2001. Produção de serapilheira em três trechos de uma floresta semidecídua com diferentes graus de perturbação na Estação Ecológica do Tripuí, Ouro Preto, MG. Revista Brasileira de Botanica. Brazilian Journal of Botany, vol. 24, no. 2, pp. 195-198. http://dx.doi.org/10.1590/S0100-84042001000200009.

WHIGHAM, D.F., OLMSTED, I., CANO, E.C. and HARMON, M.E., 1991. The impact of Hurricane Gilbert on trees, litterfall, and woody debris in a dry tropical forest in the northeastern Yucatan Peninsula. Biotropica, vol. 23, no. 4, pp. 434-441. http://dx.doi. org/10.2307/2388263.

ZHOU, G., GUAN, L., WEI, X., ZHANG, D., ZHANG, Q., YAN, J., WEN, D., LIU, J., LIU, S., HUANG, Z., KONG, G., MO, J. and YU, Q., 2007. Litterfall production along successional and altitudinal gradients of subtropical monsoon evergreen broadleaved forests in Guangdong, China. Plant Ecology, vol. 188, no. 1, pp. 77-89. http://dx.doi.org/10.1007/s11258-006-9149-9.

ZIPPARRO, V.B. 2004. Fenologia reprodutiva de espécies arbóreas em área de Floresta Atlântica no Parque Estadual Intervales - Base Saibadela, Sete Barras, SP. Rio Claro: Universidade Estadual Paulista. Tese de Doutorado em Ciências Biológicas. 